\title{
An Evaluation of Tp-e Interval and its Associations with Electrolyte Imbalances in the Electrocardiography of Elderly Patients on Hemodialysis
}

\author{
Yaşlı Hemodiyaliz Hastalarının Elektrokardiyografisinde \\ Tp-e Aralığının ve Elektrolit Bozuklukları ile İlișkisinin \\ Değerlendirilmesi
}

\begin{abstract}
Aim: Sudden cardiac death (SCD) due to arrhythmias is a major cause of death in elderly patients on hemodialysis (HD). It has been found that prolonged Tp-e interval (Tpe) on electrocardiography (ECG) and increased Tpe/QTc ratio are strongly associated with SCD. In this study, we aimed to investigate the effects of changes in serum electrolyte levels on the pre- and post-HD ECG parameters, particularly Tpe.

Methods: The study included 160 HD patients (with no disease or medication known to affect the QT interval) and 80 age- and sex-matched controls with normal kidney functions. All participants were aged 55 years or older. Pre- and post-HD serum electrolyte values and ECG recordings were obtained. The heart rate, QRS interval, QTc, Tpe, and Tpe/QTc values were calculated. The pre-HD data were compared with the post-HD data as well as with controls.

Results: The pre- and post-HD Tpe ( $p<0.001$ for both comparisons) and Tpe/QTc ( $p=0.024$ and $p<0.001$, respectively) values were significantly higher in the HD group than in the control group. The post-HD Tpe and Tpe/QTc values were significantly increased compared to the pre-HD values $(p<0.001$ for each comparison). The pre-HD Tpe was longer in patients with hypocalcemia or hyperphosphatemia than in normocalcemic and normophosphatemic patients ( $p=0.04$ for both datasets). $\Delta$ Tpe was significantly correlated with $\Delta$ calcium $(r=-0.19, p=0.02)$ and $\Delta$ phosphorus $(r=-0.23$, $\mathrm{p}=0.004$ )

Conclusion: In the elderly patients on HD, Tpe, which was prolonged before HD, was even more prolonged after HD. Hypocalcemia and hyperphosphatemia may be among the underlying factors. Keywords: electrocardiography; hemodialysis; sudden cardiac death; Tpe interval; Tpe/QTc ratio
\end{abstract}

\section{Öz}

Amaç: Aritmilere bağlı ani kardiyak ölüm (AKÖ), yașlı hemodiyaliz (HD) hastalarında bașlıca ölüm nedenlerindendir. Elektrokardiyografide (EKG) uzamıș Tp-e aralığı (Tpe) ve artmıș Tpe/QTc oranı ile AKÖ arasında güçlü bir ilișki olduğu bulunmuștur. Bu çalıșmada serum elektrolit düzeylerindeki değișikliklerin HD öncesi ve sonrası EKG parametreleri, özellikle de Tpe üzerindeki etkilerini araștırmak amaçlanmıștır.

Yöntem: Çalıșma (QT aralığını etkilediği bilinen bir hastalığı veya ilaç kullanımı olmayan) 160 HD hastası ve normal böbrek fonksiyonlarına sahip, yaș ve cinsiyet uyumlu 80 kontrol içerdi. Tüm katılımcılar 55 yaș ve üzeri idi. HD öncesi ve sonrası serum elektrolit değerleri ve EKG kayıtları elde edildi. Kalp hızı, QRS aralığı, QTc, Tpe ve Tpe/QTc değerleri hesaplandı. HD öncesi veriler, HD sonrası veriler ve kontroller ile karșılaștırıldı.

Bulgular: HD öncesi ve sonrası Tpe (iki karșılaștırma için de $p<0,001$ ) ve Tpe/QTc (sırasıyla $p=0,024$ ve $p<0,001$ ) değerleri kontrol grubuna kıyasla HD grubunda anlamlı biçimde daha yüksekti. HD sonrası Tpe ve Tpe/QTc değerleri, HD öncesi değerlere kıyasla anlamlı biçimde artmıștı (her karșılaștırma için $p<0,001)$. HD öncesi Tpe, hipokalsemi veya hiperfosfatemili hastalarda normokalsemik ve normofosfatemik hastalara göre daha uzundu (iki veri grubu için de $p=0,04$ ). $\Delta$ Tpe, $\Delta$ kalsiyum $(r=-0,19 ; p=0,02)$ ve $\Delta$ fosfor $(r=-0,23 ; p=0,004)$ ile anlamlı sekilde koreleydi.

Sonuç: Yașlı HD hastalarında HD öncesinde uzamıs olan Tpe, HD'den sonra daha da uzamıștı. Hipokalsemi ve hiperfosfatemi buna neden olan faktörlerden olabilir.

Anahtar Sözcükler: ani kardiyak ölüm; elektrokardiyografi; hemodiyaliz; Tpe aralığl; Tpe/QTc oranı
Mustafa Candemir', Mehmet Emin Demir², Burcu Candemir ${ }^{3}$, Serdar Gokhan Nurkoc

1 Department of Cardiology, Yozgat City Hospital

2 Department of Nephrology, Yozgat City Hospital

3 Department of Internal Medicine, Yozgat City Hospital

Received/Gelis : 03.09.2020 Accepted/Kabul: 02.01.2021

DOI: 10.21673/anadoluklin.790495

Corresponding author/Yazışma yazarı Mustafa Candemir

Gazi Üniversitesi Hastanesi, Kardiyoloji Bölümü, Emniyet Mah., Mevlana Bul. no. 29, 06560 Ankara, Turkey

E-mail:mstfcndmr@hotmail.com

\section{ORCID}

Mustafa Candemir: 0000-0002-3645-3912

M. Emin Demir: 0000-0003-2491-4926 Burcu Candemir:000-0003-1800-6235 S. Gokhan Nurkoc: 0000-0001-6575-9198 


\section{INTRODUCTION}

Chronic kidney disease (CKD) is one of the most prevalent diseases, affecting $13.4 \%$ of the world population, and has a strong and well-established association with cardiovascular death (1).

Hemodialysis (HD) is globally the most common type of renal replacement treatment. Sudden cardiac death (SCD) is the most common form of cardiovascular disease-related death in the HD population $(2,3)$, with an increasing incidence with age (4). It is well known that acute and chronic imbalances in serum electrolyte levels promote atrial and ventricular arrhythmias (5). In patients on HD, serum electrolytes such as potassium, calcium, magnesium, and phosphorus, which have potential effects on myocardial contractility, may deviate from the normal range and sometimes reach critical limits. Moreover, the uremic environment in HD patients may have an additive effect on arrhythmias (6). These hazardous states become more important in a long HD-free period (i.e., the Friday to Monday interval). Studies have shown that mortality and morbidity are higher in the long HD-free weekend interval (7).

Electrocardiography (ECG), is a well-established, cheap, accessible, and easy method for evaluating changes of cardiac electrical activity. Recently, Tp-e interval (Tpe), which is defined as the interval from the peak to the end of the T wave, has been found to be associated with SCD (8). Prolonged Tpe is assumed to be an ECG sign of transmural dispersion of repolarization (9). Several studies reported that prolonged Tpe and the Tpe/corrected QT (QTc) ratio were associated with malignant ventricular arrhythmias $(10,11)$. In this study, we aimed to investigate whether HD and associated electrolyte imbalances affected the Tpe and Tpe/QTc values in elderly patients.

\section{MATERIALS AND METHODS}

The cross-sectional included 160 (93 males, 67 females) consecutive HD patients at the age of 55 years and over, with a mean age of $64.80 \pm 7.09$ years. The control group consisted of 80 (40 males, 40 females) age- and sex-matched patients with normal renal functions, the mean age of whom was $63.10 \pm 6.87$ years. Only patients on HD three times a week for at least 12 months were included in the HD group, and the mean duration of HD was $65 \pm 38$ months. We excluded patients with severe coronary artery disease, ejection fraction of $<\% 50$, severe heart valve disease, complete or incomplete branch block, atrial fibrillation, resistant or uncontrolled hypertension, acute infections, hypoand hyperthyroidism, and hepatitis B or C infection. We also excluded patients fitted with a pacemaker and those on any medication that could have an impact on QT interval, such as anti-arrhythmic agents, antidepressants or inotropic drugs. Participant demographics were collected.

The study was designed to be performed in the days following the HD-free weekend interval. Pre-and post-HD blood samples were collected and pre- and post-HD ECG recordings were obtained. All patients received a standard HD prescription for the HD session on the study day. The dialysate solution consisted of glucose $(1 \mathrm{~g} / \mathrm{L})$, bicarbonate $(32 \mathrm{mmol} / \mathrm{L})$, sodium $(140 \mathrm{mmol} / \mathrm{L})$, potassium $(2 \mathrm{mmol} / \mathrm{L})$, chloride $(111$ $\mathrm{mmol} / \mathrm{L})$, calcium $(1.25 \mathrm{mmol} / \mathrm{L})$, and magnesium $(0.5$ $\mathrm{mmol} / \mathrm{L}$ ).

The pre- and post-HD serum electrolyte (potassium, phosphorus, calcium), creatinine and blood urea nitrogen levels were retrieved from the HD records. Standard echocardiographic evaluations in the parasternal and apical positions were also performed. Ejection fraction was calculated by using the modified Simpson method.

\section{Tpe measurements}

Using standard protocols (supine position, $10 \mathrm{~mm} / \mathrm{V}$ electrical activity, $25 \mathrm{~mm} / \mathrm{sec}$ writing rate), 12 -lead electrocardiograms were recorded $10 \mathrm{~min}$ before and immediately after (not exceeding $15 \mathrm{~min}$ ) the HD session by an experienced technician and evaluated by an experienced cardiologist, independent of the clinical data.

Tpe was determined as the interval between the peak and the end of the $\mathrm{T}$ wave. The end of the $\mathrm{T}$ wave was defined as the intersection between the tangent of the descending limb of the $\mathrm{T}$ wave and the isoelectric line. At least five consequent $\mathrm{T}$-waves were analyzed in precordial leads. The mean values of the data were obtained. A high-resolution camera was used to magnify $\mathrm{T}$-waves for calculation. The QT interval was measured from the beginning of the QRS complex to the end of 
Table 1. Demographic and laboratory characteristics

\begin{tabular}{|c|c|c|c|}
\hline & The HD group $(n=160)$ & The control group $(\mathrm{n}=\mathbf{8 0})$ & $p$ \\
\hline Age (years), mean \pm SD & $64.80 \pm 7.09$ & $63.10 \pm 6.87$ & 0.11 \\
\hline Sex (male), n (\%) & $93(58.1)$ & $40(50)$ & 0.29 \\
\hline Hypertension, n (\%) & $66(41.3)$ & $28(35)$ & 0.29 \\
\hline Diabetes mellitus, n (\%) & $56(35)$ & $20(25)$ & 0.20 \\
\hline Smokers, n (\%) & $45(28.1)$ & $25(31.2)$ & 0.62 \\
\hline $\operatorname{LVEF}(\%)$, mean \pm SD & $61.31 \pm 3.18$ & $61.20 \pm 3.28$ & 0.81 \\
\hline Hemoglobin $(\mathrm{g} / \mathrm{dL})$, mean \pm SD & $11.04 \pm 1.87$ & $13.25 \pm 2.38$ & 0.04 \\
\hline Platelets $\left(\mathrm{x}^{3} 0^{3} / \mu \mathrm{L}\right)$, mean $\pm \mathrm{SD}$ & $204.10 \pm 64.61$ & $221.32 \pm 57.27$ & 0.12 \\
\hline $\mathrm{WBC}\left(\mathrm{x} 10^{3} / \mu \mathrm{L}\right)$, mean $\pm \mathrm{SD}$ & $7.44 \pm 2.26$ & $7.50 \pm 3.08$ & 0.16 \\
\hline Albumin (g/dL), median (IR) & $3.81(3.40-3.90)$ & $4.11 \pm 0.41$ & 0.03 \\
\hline Total protein $(\mathrm{g} / \mathrm{dL})$, median (IR) & $6.60(6.30-7.00)$ & $7.12 \pm 0.81$ & 0.08 \\
\hline
\end{tabular}

IR: interquartile range; LVEF: left ventricular ejection fraction; SD: standard deviation; WBC: white blood cell

Table 2. The pre- and post-HD values (mean \pm standard deviation) as compared to the control values

\begin{tabular}{lllllll}
\hline & Pre-HD (1) & Post-HD (2) & Control (3) & $p(\mathbf{1 - 3})$ & $p(\mathbf{2}-3)$ & $p(\mathbf{1 - 2})$ \\
\hline Urea (mg/dL) & $134.76 \pm 32.13$ & $40.53 \pm 14.99$ & $33.88 \pm 9.12$ & $<0.001$ & 0.001 & $<0.001$ \\
Creatinine (mg/dL) & $7.59 \pm 2.42$ & $2.91 \pm 1.18$ & $0.87 \pm 0.21$ & $<0.001$ & $<0.001$ & $<0.001$ \\
Potassium (mmol/L) & $5.44 \pm 0.75$ & $3.58 \pm 0.46$ & $4.19 \pm 0.45$ & $<0.001$ & $<0.001$ & $<0.001$ \\
Phosphorus (mg/dl) & $5.08 \pm 1.38$ & $3.43 \pm 0.52$ & $3.26 \pm 0.63$ & $<0.001$ & 0.21 & $<0.001$ \\
Calcium (mg/dl) & $8.77 \pm 0.79$ & $9.43 \pm 0.51$ & $9.63 \pm 0.48$ & $<0.001$ & $<0.001$ & $<0.001$ \\
Heart rate (beat/min) & $77.06 \pm 12.64$ & $80.91 \pm 12.99$ & $78.00 \pm 8.05$ & 0.52 & 0.06 & $<0.001$ \\
QRS interval (ms) & $87.02 \pm 14.09$ & $88.30 \pm 13.73$ & $87.51 \pm 13.98$ & 0.82 & $<0.001$ & 0.006 \\
QTc interval (ms) & $420.30 \pm 37.72$ & $414.11 \pm 44.02$ & $395.35 \pm 30.96$ & $<0.001$ & 0.001 & 0.06 \\
Tpe (ms) & $73.64 \pm 9.61$ & $81.09 \pm 10.20$ & $66.13 \pm 7.44$ & $<0.001$ & $<0.001$ & $<0.001$ \\
Tpe/QTc ratio & $0.18 \pm 0.02$ & $0.20 \pm 0.03$ & $0.17 \pm 0.02$ & 0.024 & $<0.001$ & $<0.001$
\end{tabular}

Table 3. Correlation analysis of the $\Delta$ Tpe and laboratory results

\begin{tabular}{lll}
\hline & \multicolumn{1}{c}{$\Delta$ Tpe } \\
\cline { 2 - 3 }$r$ coefficient & $p$ value \\
\hline Age & 0.13 & 0.11 \\
$\Delta$ urea & -0.85 & 0.28 \\
$\Delta$ creatinine & -0.11 & 0.16 \\
$\Delta$ potassium & -0.13 & 0.09 \\
$\Delta$ calcium & -0.19 & 0.02 \\
$\Delta$ phosphorus & -0.23 & 0.004 \\
\hline
\end{tabular}

the $\mathrm{T}$ wave and corrected according to heart rate by

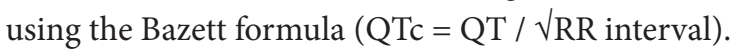

Subjects with U-waves on ECGs were removed from the study. T-waves with amplitudes of $<0.1 \mathrm{mV}$, negative T-waves, two-phase and notched $\mathrm{T}$ waves were not analyzed.
Table 4. Correlation analysis of the $\Delta \mathrm{QTc}$ and laboratory results

\begin{tabular}{lll}
\hline & $\Delta \mathbf{Q T c}$ & \\
\cline { 2 - 3 } & $\boldsymbol{r}$ coefficient & $\boldsymbol{p}$ value \\
\hline Age & 0.02 & 0.79 \\
$\Delta$ urea & 0.17 & 0.03 \\
$\Delta$ creatinine & 0.15 & 0.06 \\
$\Delta$ potassium & 0.04 & 0.60 \\
$\Delta$ calcium & 0.66 & 0.001 \\
$\Delta$ phosphorus & 0.70 & 0.001 \\
\hline
\end{tabular}

\section{Statistical analysis}

Statistical analysis was done using the SPSS (21.0) software (SPSS Inc., Chicago, IL, USA). Normal distribution was assessed by the Kolmogorov-Smirnov test. Descriptive data were expressed as means and standard deviations for normally distributed (parametric) data and medians (interquartile range) for non-nor- 
mally distributed (non-parametric) data. Categorical variables were expressed as percentages. Mean values were compared between the groups by using the independent t-test, while the Mann-Whitney $U$ test was used for the comparison of medians. Categorical data were compared by Pearson's chi-square analysis. Preand post-HD electrocardiographic data were compared by the paired samples t-test or Wilcoxon signed ranks test, depending on the normality of the data. For all tests, a 2 -tailed $\mathrm{p}<0.05$ was considered statistically significant.

\section{Study ethics}

The study protocol was approved by the local ethics committee (approval no. 2017-KAEK189_2020.06.23_04). Written informed consent was obtained from all participants, in accordance with the Declaration of Helsinki.

\section{RESULTS}

The clinical and laboratory characteristics of participants are presented in Table 1. As expected, the serum urea and creatinine levels were higher in the HD group than in the control group. The electrolyte, calcium, phosphorus, and potassium values were within the normal range or slightly higher in the pre-HD period and were found to be substantially decreased after HD ( $\mathrm{p}<0.001$ for each comparison).

The mean heart rate and QRS interval values were higher after HD $(77.06 \pm 12.64$ vs. $80.91 \pm 12.99$, $\mathrm{p}=<0.001 ; 87.02 \pm 14.09$ vs. $88.30 \pm 13.73, \mathrm{p}=0.006$, respectively). The mean QTc interval tended to be shorter after HD (420.30 \pm 37.72 vs. $414.11 \pm 44.02, \mathrm{p}=0.06)$. Tpe was longer in the pre-HD group than in the control group, and further increased after HD (66.13 \pm 7.44 vs. $73.64 \pm 9.61$ vs. $81.09 \pm 10.20$, respectively, $\mathrm{p}=0.001$ for all). Similarly, the Tpe/QTc ratio was higher in the pre-HD group than in the control group $(0.18 \pm 0.02$ vs. $0.17 \pm 0.02, p=0.024)$ and was further increased after HD ( $0.18 \pm 0.02$ vs. $0.20 \pm 0.03, \mathrm{p}=0.001)$ (Table 2).

Before HD, Tpe was longer in hypocalcemic than in normocalcemic patients ( $76 \pm 9$ vs. $72 \pm 9 \mathrm{~ms}, \mathrm{p}=0.04$ ) (Figure 1) and in hyperphosphatemic than in normophosphatemic patients $(75 \pm 10$ vs. $72 \pm 9 \mathrm{~ms}, \mathrm{p}=0.04)$ (Figure 2). $\Delta$ Tpe was correlated with $\Delta$ calcium (r=-
$0.19, \mathrm{p}=0.02)$ and $\Delta$ phosphorus $(\mathrm{r}=-0.23, \mathrm{p}=0.004)$. There was a correlation between $\Delta$ Tpe and $\Delta$ potassium $(\mathrm{r}=-0.13, \mathrm{p}=0.09)$ (Table 3). $\Delta \mathrm{QTC}$ was correlated with $\Delta$ urea $(\mathrm{r}=0.17, \mathrm{p}=0.03), \Delta$ calcium $(\mathrm{r}=0.66, \mathrm{p}=0.001)$, and $\Delta$ phosphorus $(\mathrm{r}=0.70, \mathrm{p}=0.001)$. There was a strong correlation between $\Delta$ Tpe and $\Delta$ creatinine $(r=0.15$, $\mathrm{p}=0.06)$ (Table 4).

\section{DISCUSSION AND CONCLUSION}

SCD is the major cardiovascular cause of death in patients on HD. Uremic conditions and electrolyte imbalances have an additive effect on conventional risk factors for cardiovascular disease-related death in the HD population (2). ECG is the most feasible and useful tool in clinical practice to determine cardiovascular disease. We demonstrated that Tpe and Tpe/QTc values were altered in elderly patients on $\mathrm{HD}$ and exhibited significant changes during HD sessions. These changes might increase the risk of SCD in the HD population. In our study, in consistence with previous studies $(12,13)$, we found that the Tpe and Tpe/QTc values were increased after $\mathrm{HD}$, and that they were higher in the HD group than in the control group. We also found that Tpe and QTc were associated with $\Delta$ calcium and $\Delta$ phosphorus. In addition, Tpe was longer in hypocalcemic and hyperphosphatemic patients before HD.

$\mathrm{HD}$ is the most prevalent type of renal replacement treatment in end-stage kidney disease (14). Although there have been many innovations in the HD practice (new biocompatible membranes, enhanced volumecontrolled devices, new drugs targeting complications of end-stage kidney disease), the mortality and morbidity rates are still markedly high compared to HDfree individuals $(15,16)$. Rapid electrolyte changes during HD sessions are among the factors associated with cardiovascular disease-related mortality. Rapid calcium and phosphorus changes have been particularly linked to the high rates of mortality in HD patients $(17,18)$. Moreover, HD itself is associated with several risk factors for death, such as hypotension episodes and rapid electrolyte changes. It is likely that many benefits of $\mathrm{HD}$ are balanced by such complications.

Most HD centers make ECG assessments every 3 to 6 months to determine ECG changes. Subacute and 


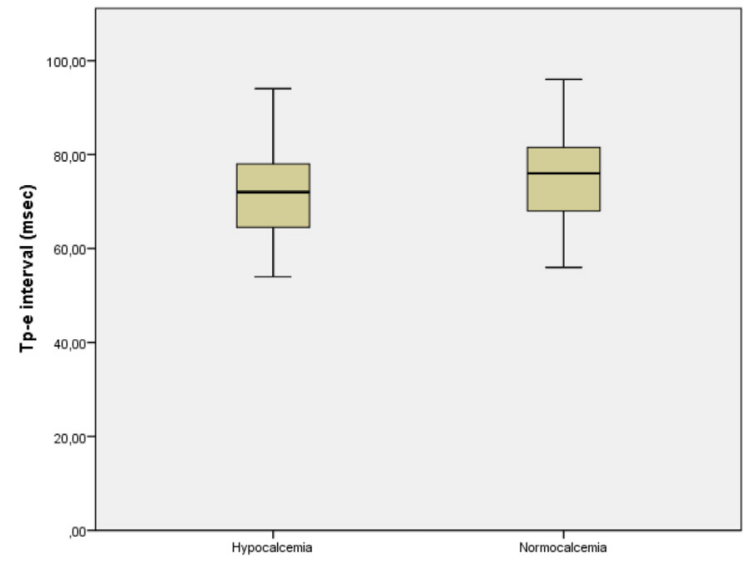

Figure 1. Tpe interval was higher in hypocalcemic than in normocalcemic patients before HD

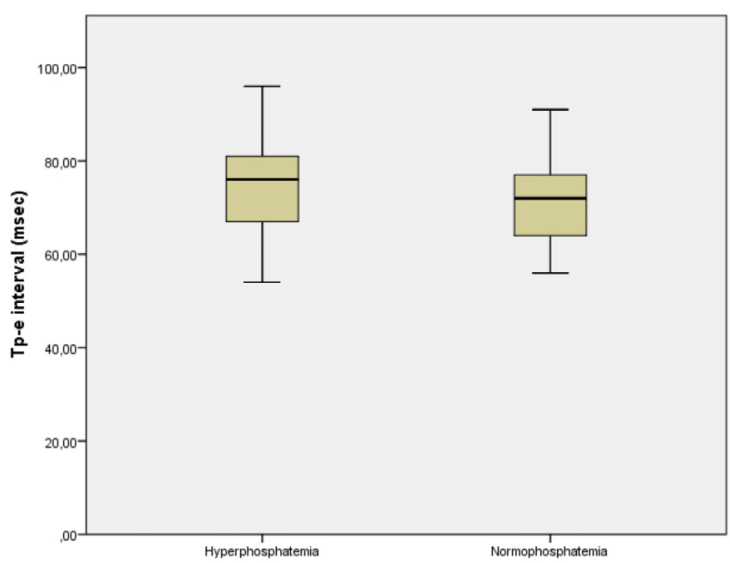

Figure 2. Tpe interval was higher in hyperphosphatemic than in normophosphatemic patients before HD

chronic ECG changes are discussed with a cardiologist as many patients on HD are lost due to SCD (3). A study reported that 143 (65\%) of 221 outpatients on HD had ECG abnormalities (19). Awareness of early ECG changes and properly modifying the HD prescription and other, conventional risk factors might save the lives of patients (20). Numerous electrocardiographic changes have been identified as having the potential to lead to cardiac arrhythmias, including changes of Tpe, Tpe/QTc ratio, and QTc duration $(10,11)$.

QT and T-wave analysis on ECG is used to evaluate ventricular repolarization. While the peak point of the T-wave displays the epicardial repolarization, the end of the T-wave shows the repolarization of M-cells (the cells between the endocardial and epicardial layers) (9). Hence, Tpe is a measurement of total dispersion of repolarization. Consequently, an increase in Tpe or
Tpe/QTc may result in fatal arrhythmias. In our study, both pre-HD and post-HD Tpe and Tpe/QTc values were significantly higher in the HD group than in the control group. Also, as in previous studies $(21,22)$, the values were significantly increased after HD. Tpe prolongation has also been reported in type 2 diabetes mellitus (23), hypertrophic cardiomyopathy (24), and subclinical hypothyroidism (25). It needs further investigation whether the high mortality rates associated with these clinical entities are related to such ECG changes. In the HD population, diabetes mellitus, hypertension, cardiac diseases, and other chronic diseases which contribute to mortality are also prevalent, and in our study $41.3 \%$ and $35 \%$ of the patients had hypertension and diabetes, respectively.

Reports on the QTc duration before and after HD are controversial. Although there are studies showing that the QTc interval increases after HD $(12,26)$, other studies, such as ours, have shown that it is decreased (27-30). It has been suggested that the increase in nitric oxide after HD (31) and the change of the reninangiotensin system in HD patients (32) reduce QTc with various effects. Tang et al. showed that increased uremic toxins caused QTc prolongation (33). In our study, the change in urea levels was found to be correlated with the change in QTc.

It is well known that calcium affects the electrical conduction time (duration of action potential) of the myocardium (12). Similar to previous studies $(12,34,35)$, we observed Tpe prolongation in hypercalcemic patients before HD. Furthermore, as $\Delta$ calcium increased, $\Delta \mathrm{QT}$ prolongation and $\Delta$ Tpe duration also increased.

Hyperphosphatemia in chronic renal failure causes an increase in fibroblast growth factor 23 (FGF23) and results in parathyroid hormone resistance in the skeletal system. FGF23 contributes to hypocalcemia by suppressing the calcitriol production (36-38). On the other hand, hyperphosphatemia has been shown to play a role in cardiac fibrosis (39). It has been previously reported that hyperphosphatemia in HD patients reduces heart rate variability, which is indicative of cardiac autonomic system dysfunction (40). These effects suggest that hyperphosphatemia may have an effect on action potential in myocytes. In our study, we found that Tp-e interval increased in hyperphosphate- 
mia before HD. We also found that the post-HD phosphorus change had an effect on $\Delta \mathrm{QTc}$ and $\Delta \mathrm{Tpe}$. Accordingly, HD prescription needs to be modified with caution, especially in patients with high phosphorus or low calcium levels before HD.

Finally, our sample size was greater than that of most previous studies and, to our knowledge, this was a first study in elderly HD patients on this subject. However, our study also has several limitations. We did not have patient follow-up data on ventricular arrhythmias, and we did not evaluate parameters such as arterial $\mathrm{pH}$, bicarbonate (HCO3-), and fluid changes. Detailed evaluations of echocardiographic parameters together with Tpe and Tpe/QTc values could be beneficial. In conclusion, many elderly patients on HD exhibit ECG changes, including prolonged Tpe and increased Tpe/QTc values, and there is a need for further longitudinal studies to investigate whether these changes are related to increased morbidity and mortality as well as to SCD.

\section{Conflict-of-Interest and Financial Disclosure}

The authors declare that they have no conflict of interest to disclose. The authors also declare that they did not receive any financial support for the study.

\section{REFERENCES}

1. Hill NR, Fatoba ST, Oke JL, Hirst JA, O’Callaghan CA, Lasserson DS, et al. Global prevalence of chronic kidney disease-a systematic review and meta-analysis. PloS One. 2016;11(7):e0158765.

2. Green D, Roberts PR, New DI, Kalra PA. Sudden cardiac death in hemodialysis patients: an in-depth review. Am J Kidney Dis. 2011;57(6):921-9.

3. Makar MS, Pun PH. Sudden cardiac death among hemodialysis patients. Am J Kidney Dis. 2017;69(5):684-95.

4. Eckart RE, Shry EA, Burke AP, McNear JA, Appel DA, Castillo-Rojas LM, et al. Sudden death in young adults: an autopsy-based series of a population undergoing active surveillance. J Am Coll Cardiol. 2011;58(12):125461.

5. Nishimura M, Nakayama K, Ishikawa Y. Cardiac arrhythmias caused by electrolyte imbalance [article in Japanese]. Nihon Rinsho. 1996;54(8):2207-12.

6. Stewart GA, Gansevoort RT, Mark PB, Rooney E, McDonagh TA, Dargie HJ, et al. Electrocardiographic ab- normalities and uremic cardiomyopathy. Kidney Int. 2005;67(1):217-26.

7. Bleyer AJ, Hartman J, Brannon PC, Reeves-Daniel A, Satko SG, Russell G. Characteristics of sudden death in hemodialysis patients. Kidney Int. 2006;69(12):2268-73.

8. Panikkath R, Reinier K, Uy-Evanado A, Teodorescu C, Hattenhauer J, Mariani R, et al. Prolonged Tpeakto-tend interval on the resting ECG is associated with increased risk of sudden cardiac death. Circ Arrhythm Electrophysiol. 2011;4(4):441-7.

9. Antzelevitch C, Shimizu W, Yan GX, Sicouri S, Weissenburger J, Nesterenko VV, et al. The M cell: its contribution to the ECG and to normal and abnormal electrical function of the heart. J Cardiovasc Electrophysiol. 1999;10(8):1124-52.

10. Hevia JC, Antzelevitch C, Barzaga FT, Sanchez MD, Balea FD, Molina RZ, et al. Tpeak-Tend and Tpeak-Tend dispersion as risk factors for ventricular tachycardia/ ventricular fibrillation in patients with the Brugada syndrome. J Am Coll Cardiol. 2006;47(9):1828-34.

11. Erikssen G, Liestol K, Gullestad L, Haugaa KH, Ben$\mathrm{dz}$ B, Amlie JP. The terminal part of the QT interval ( $\mathrm{T}$ peak to $\mathrm{T}$ end): a predictor of mortality after acute myocardial infarction. Ann Noninvasive Electrocardiol. 2012;17(2):85-94.

12. Jaroszynski AJ, Zaluska WT, Ksiazek A. Effect of haemodialysis on regional and transmural inhomogeneities of the ventricular repolarisation phase. Nephron Clin Pract. 2005;99(1):c24-30.

13. Ozportakal H, Ozkok A, Alkan O, Bulut AS, Boyraz M, Inanir $\mathrm{M}$, et al. Hemodialysis-induced repolarization abnormalities on ECG are influenced by serum calcium levels and ultrafiltration volumes. Int Urol Nephrol. 2017;49(3):509-15.

14. Grassmann A, Gioberge S, Moeller S, Brown G. ESRD patients in 2004: global overview of patient numbers, treatment modalities and associated trends. Nephrol Dial Transplant. 2005;20(12):2587-93.

15. Uda S, Mizobuchi M, Akizawa T. Biocompatible characteristics of high-performance membranes. Contrib Nephrol. 2011;173:23-9.

16. Chandrashekar A, Ramakrishnan S, Rangarajan D. Survival analysis of patients on maintenance hemodialysis. Indian J Nephrol. 2014;24(4):206-13.

17. Rodriguez-Benot A, Martin-Malo A, Alvarez-Lara MA, Rodriguez M, Aljama P. Mild hyperphosphatemia and mortality in hemodialysis patients. Am J Kidney Dis. 2005;46(1):68-77.

18. Severi S, Grandi E, Pes C, Badiali F, Grandi F, Santoro 
A. Calcium and potassium changes during haemodialysis alter ventricular repolarization duration: in vivo and in silico analysis. Nephrol Dial Transplant. 2008;23(4):1378-86.

19. Abe S, Yoshizawa M, Nakanishi N, Yazawa T, Yokota $\mathrm{K}$, Honda $\mathrm{M}$, et al. Electrocardiographic abnormalities in patients receiving hemodialysis. Am Heart J. 1996;131(6):1137-44.

20. Shapira OM, Bar-Khayim Y. ECG changes and cardiac arrhythmias in chronic renal failure patients on hemodialysis. J Electrocardiol. 1992;25(4):273-9.

21. Kalantzi K, Gouva C, Letsas KP, Vlachopanou A, Foulidis V, Bechlioulis A, et al. The impact of hemodialysis on the dispersion of ventricular repolarization. Pacing Clin Electrophysiol. 2013;36(3):322-7.

22. Sivri S, Celik M. Evaluation of index of cardiac-electrophysiological balance before and after hemodialysis in patients with end-stage renal disease. J Electrocardiol. 2019;54:72-5.

23. Tokatli A, Kilicaslan F, Alis M, Yiginer O, Uzun M. Prolonged Tp-e interval, Tp-e/QT ratio and Tp-e/QTc ratio in patients with type 2 diabetes mellitus. Endocrinol Metab. 2016;31(1):105-12.

24. Akboga MK, Gulcihan Balci K, Yilmaz S, Aydin S, Yayla C, Ertem AG, et al. Tp-e interval and Tp-e/QTc ratio as novel surrogate markers for prediction of ventricular arrhythmic events in hypertrophic cardiomyopathy. Anatol J Cardiol. 2017;18(1):48-53.

25. Gurdal A, Eroglu H, Helvaci F, Sumerkan MC, Kasali K, Cetin S, et al. Evaluation of Tp-e interval, Tp-e/QT ratio and Tp-e/QTc ratio in patients with subclinical hypothyroidism. Ther Adv Endocrinol Metab. 2017;8(3):25-32.

26. Covic A, Diaconita M, Gusbeth-Tatomir P, Covic M, Botezan A, Ungureanu G, et al. Haemodialysis increases QT(c) interval but not QT(c) dispersion in ESRD patients without manifest cardiac disease. Nephrol Dial Transplant. 2002;17(12):2170-7.

27. Severi S, Ciandrini A, Grandi E, Cavalcanti S, Bini S, Badiali F, et al. Cardiac response to hemodialysis with different cardiovascular tolerance: heart rate variability and QT interval analysis. Hemodial Int. 2006;10(3):287-93.

28. Astan R, Akpinar I, Karan A, Kacmaz F, Sokmen E, Baysal E, et al. The effect of hemodialysis on electrocardiographic parameters. Ann Noninvasive Electrocardiol. 2015;20(3):253-7.

29. Drighil A, Madias JE, Benjelloun M, Kamoum H, Bennis A, Azzouzi L, et al. Changes in the QT intervals, QT dispersion, and amplitude of $\mathrm{T}$ waves after hemodialysis. Ann Noninvasive Electrocardiol. 2007;12(2):137-44.
30. Alabd MA, El-Hammady W, Shawky A, Nammas W, ElTayeb M. QT interval and QT dispersion in patients undergoing hemodialysis: revisiting the old theory. Nephron Extra. 2011;1(1):1-8.

31. Kulmatycki KM, Abouchehade K, Sattari S, Jamali F. Drug-disease interactions: reduced beta-adrenergic and potassium channel antagonist activities of sotalol in the presence of acute and chronic inflammatory conditions in the rat. Br J Pharmacol. 2001;133(2):286-94.

32. Murasawa T, Sakai Y, Sakai S, Ohtsuka T, Ohno D, Amitani K, et al. QT dispersion increases during hemodialysis procedures in patients undergoing maintenance dialysis: association with an RA system and holter electrocardiogram. Nihon Jinzo Gakkai Shi. 2008;50(4):481-7.

33. Tang WH, Wang CP, Chung FM, Huang LL, Yu TH, Hung WC, et al. Uremic retention solute indoxyl sulfate level is associated with prolonged QTc interval in early CKD patients. PloS One. 2015;10(3):e0119545.

34. Nappi SE, Virtanen VK, Saha HH, Mustonen JT, Pasternack AI. QTc dispersion increases during hemodialysis with low-calcium dialysate. Kidney Int. 2000;57(5):2117-22.

35. Yetkin E, Ileri M, Tandogan I, Boran M, Yanik A, Hisar I, et al. Increased QT interval dispersion after hemodialysis: role of peridialytic electrolyte gradients. Angiology. 2000;51(6):499-504.

36. Slatopolsky E. New developments in hyperphosphatemia management. J Am Soc Nephrol. 2003;14(9 Suppl 4):S297-9.

37. Savica V, Calo LA, Monardo P, Santoro D, Bellinghieri G. Phosphate binders and management of hyperphosphataemia in end-stage renal disease. Nephrol Dial Transplant. 2006;21(8):2065-8.

38. Imanishi $Y$, Inaba $M$, Nakatsuka $K$, Nagasue $K$, Okuno S, Yoshihara A, et al. FGF-23 in patients with end-stage renal disease on hemodialysis. Kidney Int. 2004;65(5):1943-6.

39. Amann K, Tornig J, Kugel B, Gross ML, Tyralla K, ElShakmak A, et al. Hyperphosphatemia aggravates cardiac fibrosis and microvascular disease in experimental uremia. Kidney Int. 2003;63(4):1296-301.

40. Wang Q, Cui Y, Yogendranath P, Wang N. Blood pressure and heart rate variability are linked with hyperphosphatemia in chronic kidney disease patients. Chronobiol Int. 2018;35(10):1329-34. 